\title{
Analisis Pendapatan Usahatani Kangkung Darat di Desa Takin Kecamatan Bikomi Tengah Kabupaten Timor Tengah Utara
}

Maria Goreti Tasi Mona ${ }^{\mathrm{a}}$, dan Yosefina Marice Fallo ${ }^{\mathrm{b}}$

${ }^{a}$ Fakultas Pertanian, Universitas Timor, Kefamenanu, TTU - NTT, Indonesia.

${ }^{b}$ Fakultas Pertanian, Universitas Timor, Kefamenanu, TTU - NTT, Indonesia.

\section{Article Info}

Article history:

Received 22 Januari 2018

Received in revised form 27 Februari 2018

Accepted 18 Maret 2018

\section{Keywords:}

Pendapatan

Usahatani

Kangkung Darat

Takin

Bikomi Tengah

\section{Abstrak}

Timor Tengah Utara (TTU) merupakan kabupaten yang sebagian masyarakat berusahatani sayur-sayuran untuk memenuhi kebutuhan hidup dan juga untuk diperdagangkan. Desa Takin adalah salah satu desa yang memproduksi sayur seperti sayur kangkung darat terbanyak di kecamatan Bikomi Tengah, kabupaten TTU tetapi petani di desa Takin tidak melakukan analisis usahatani untuk mengetahui besarnya biaya produksi, penerimaan dan pendapatan mereka dari usahatani kangkung darat. Tujuan penelitian ini adalah untuk mengetahui 1) gambaran usahatani kangkung darat; 2) pendapatan yang diperoleh dari usahatani kangkung darat; dan 3) keuntungan relatif yang diperoleh dari usahatani sayur kangkung darat di desa Takin, kecamatan Bikomi Tengah, kabupaten TTU. Penelitian dilaksanakan di desa Takin, kecamatan Bikomi Tengah, Kabupaten TTU, pada bulan Oktober 2017 sampai Januari 2018. Populasi dalam penelitian ini adalah semua petani di desa Takin, yang mengusahakan kangkung darat yang berjumlah $150 \mathrm{KK}$ dengan metode pengambilan sampel purposive sampling sehingga diambil 40 responden. Pertimbangan utama dalam penentuan sampel adalah responden telah mengusahakan sayur kangkung dara paling tidak tiga tahun atau lebih. Untuk mengetahui gambaran umum usahatani sawi maka digunakan metode analisis deskriptif kualitatif, sedangkan mengetahui pendapatan usahatani kangkung darat maka dilakukan analisis pendapatan. Untuk mengetahui keuntungan relatif dari usahatani sayur kangkung darat digunakan analisis R/C Rasio. Hasil penelitian menunjukkan tahapan usahatani kangkung darat yang dilakukan di desa Takin meliputi persiapan lahan, pemberian pupuk dasar, penanaman, pemeliharaan, panen dan pasca panen. Biaya yang dikeluarkan meliputi biaya tetap dan biaya variabel dengan rata-rata biaya sebesar Rp333.960,41 dan total biaya sebesar Rp13.358.416,67. Total penerimaan usahatani kangkung darat dalam satu kali musim tanam sebesar Rp102.250.000,00 sehingga petani memperoleh ratarata permintaan sebesar Rp2.556.250,00. Total pendapatan kangkung darat sebesar Rp88.891.583,33 dengan rata-rata pendapatan sebesar Rp2.222.289,58. Rata-rata nilai R/C Ratio adalah 7,36 sehingga kegiatan usahatani kangkung darat yang dilakukan oleh petani di desa Takin layak untuk dikembangkan karena menguntungkan secara ekonomis. (22018 dipublikasikan oleh Agrimor.

\section{Pendahuluan}

Timor Tengah Utara (TTU) merupakan kabupaten yang sebagian masyarakatnya berusahatani sayur-sayuran untuk memenuhi kebutuhan hidup dan juga untuk diperdagangkan. Beberapa penelitian terdahulu member gambaran bahwa usahatani sayur-sayuran di kabupaten TTU menguntungkan secara ekonomi bagi petani, misalnya usahatani sawi di desa Humusu Oekolo (Nubatonis, 2016), atau di kelurahan Oelami (Opat \& Hutapea, 2017). Usahatan cabe rawit merah di desa Tapenpah (Haki \& Taena, 2017) juga menguntungkan secara ekonomi. Hal ini membuktikan bahwa peluang pasar sayur-sayuran di kabupaten TTU cukup menjanjikan. Bahkan menurut Pay \& Nubatonis, (2017) komoditi sayuran jenis buncis yang diproduksi di desa Oerinbesi kabupaten TTU telah dipasarkan hingga konsumen yang berada di Kupang. Hal ini karena letak kabupaten TTU yang berada di tengah pulau Timor sehingga komoditi sayuran yang diproduksi mudah dipasarkan di berbagai kabupaten lain hingga ke Kupang sebagai ibu kota provinsi. Selain itu, hasil penelitian Taena, (2009) juga memberikan gambaran bahwa beberapa komoditi pertanian juga menjadi bahan yang diperdagangkan di perbatasan dengan negara Timor Leste. Hal in menunjukkan bahwa terbuka peluang pasar perbatasan yang bisa dimanfaatkan untuk pemasaran komoditi sayur-sayuran yang diproduksi di kabupaten TTU.

Salah satu jenis sayuran yang banyak dibudidayakan di kabupaten TTU adalah kangkung darat. Rukmana, (1994) menyebutkan kegunaan sayuran kangkung selain sumber vitamin A dan mineral serta unsur gizi lainnya yang berguna bagi kesehatan tubuh juga dapat berfungsi untuk menenangkan syaraf atau berkhasiat sebagai obat tidur bagian tanaman kangkung yang paling penting adalah batang muda dan pucuk sebagai bahan sayur mayur. Selanjutnya menuru Rahman \& Parkpain, (2004) konsumsi kangkung kemungkinan akan meningka seiring dengan meningkatnya kesadaran masyarakat terhadap makanan yang bergizi. Kandungan gizi kangkung cukup tinggi, terutama vitamin A, vitamin C, zat besi, kalsium, potasium, dan fosfor.

Produksi kangkung darat di kabupaten TTU tahun 2013-2016 berturut-turu adalah 112,1 ton, 81,8 ton, 71,1 ton, dan 44,8 ton (BPS Kab. TTU, 2017). Data ini menunjukkan bahwa terjadi penurunan produksi dari tahun ke tahun, padaha usahatani kangkung di kabupaten TTU menguntungkan secara ekonomi. Tani' \& Kune, (2016) menyatakan bahwa setiap pengeluaran Rp1,00 dalam usahatan kangkung di kelurahan Bansone akan memberikan penerimaan sebesar Rp4,00.

Desa Takin adalah salah satu desa yang memproduksi sayur seperti sayur kangkung darat terbanyak di kecamatan Bikomi Tengah, kabupaten TTU, hal in didukung dengan keadaan wilayah yang sangat strategis dan cocok untuk berusahatani sayur karena memiliki sumberdaya air yang berlimpah sehingga masyarakat dengan penuh semangat untuk memproduksi sayur kangkung. Sistim penjualan sayur kangkung darat yang dilakukan di desa Takin adalah penjualan dalam bentuk ikat, setelah diikat petani langsung menjualnya ke pasa Kefamenanu, ada juga pedagang sayur yang langsung datang membeli sayur kangkung di kebun petani untuk kemudian dijual.

Petani di desa Takin tidak melakukan analisis usahatani untuk mengetahui besarnya biaya produksi, penerimaan dan pendapatan mereka dari usahatan kangkung darat, padahal menurut Pitojo, (2005) analisis usahatani merupakan gambaran yang perlu dicermati manakala akan melakukan usahatani, serta juga ditegaskan bahwa data usahatani bersifat situasional dan kedaerahan karena dipengaruhi oleh input produksi, tenaga kerja setempat, dan hasil serta harga yang berlaku. Selanjutnya menurut Haryanto, (2007) agar suatu usahatani tidak rugi maka harus diketahui terlebih dahulu analisis usahataninya, hal-hal yang perlu diketahui antara lain berapa modal yang dibutuhkan, berapa nilai titik impas dan berapa nilai perbandingan antara penerimaan dengan biaya. Suratiyah, (2006) juga menyatakan bahwa dengan memahami data-data usahatani maka petani dapat merencanakan produksi sesuai dengan pendapatan yang diinginkan. Untuk itu maka perlu dilakukan kajian dengan topik "Analisis Pendapatan Usahatani Kangkung Darat di Desa Takin Kecamatan Bikomi Tengah Kabupaten Timor Tengah Utara". Tujuan penelitian ini adalah untuk mengetahui 1) gambaran usahatani kangkung darat; 2) pendapatan yang diperoleh dari usahatani kangkung darat; dan 3) keuntungan relatif yang diperoleh dari usahatani sayur kangkung darat di desa Takin, kecamatan Bikomi Tengah, kabupaten TTU.

\section{Metode}

Penelitian dilaksanakan di desa Takin, kecamatan Bikomi Tengah, Kabupaten TTU, pada bulan Oktober 2017 sampai Januari 2018. Populasi dalam penelitian ini adalah semua petani di desa Takin, kecamatan Bikomi Tengah yang mengusahakan kangkung darat yang berjumlah $150 \mathrm{KK}$. Teknik pengambilan sampel dalam penelitian ini menggunakan teknik metode purposive sampling sesuai petunjuk Ating \& Sambas, (2006) sehingga diambil 40 responden. Pertimbangan utama dalam penentuan sampel adalah responden telah mengusahakan sayur kangkung darat paling tidak tiga tahun atau lebih.

Data yang digunakan dalam penelitian ini adalah data primer yang diperoleh dengan teknik wawancara langsung dengan responden atau petani pengusah kangkung darat di lokasi penelitian berdasarkan daftar pertanyaan yan disiapkan oleh peneliti sedangkan data sekunder diperoleh dari instansi atau lembaga terkait.

Data yang diperoleh dikumpulkan kemudian ditabulasi dan dianalisis berdasarkan tujuan penelitian. Untuk mengetahui gambaran umum usahatan sawi maka digunakan metode analisis deskriptif kualitatif sesuai petunjuk Sugiyono, (2006), sedangkan mengetahui pendapatan usahatani kangkung darat maka dilakukan analisis pendapatan sesuai petunjuk Soekartawi, (1995), dengan formula:

$$
\begin{aligned}
& \mathrm{Pd}=\mathrm{TR}-\mathrm{TC} \\
& \mathrm{TR}=\mathrm{Py} . \mathrm{Y} \\
& \mathrm{TC}=\mathrm{FRC}+\mathrm{VC} \\
& \text { Sehingga Pd }=\{[\mathrm{Py} . \mathrm{Y}] /[\mathrm{FC}+\mathrm{VC}]\} \text { dimana: } \\
& \mathrm{Pd}=\text { Pendapatan usahatani kangkung darat } \\
& \mathrm{Py}=\text { Harga sayur kangkung darat } \\
& \mathrm{Y}=\text { Produksi yang diperoleh } \\
& \mathrm{FC}=\text { Biaya tetap } \\
& \mathrm{VC}=\text { Biaya variabel }
\end{aligned}
$$

Untuk mengetahui keuntungan relatif dari usahatani sayur kangkung darat digunakan analisis R/C Ratio sesuai petunjuk Soekartawi, (1993) dengan formula $\mathrm{R} / \mathrm{C}$ Ratio = Total Penerimaan / Total Biaya dengan kriteria yang digunakan adalah:

$\mathrm{R} / \mathrm{C}>1$ : Secara ekonomis mengalami keuntungan

$\mathrm{R} / \mathrm{C}=1$ : Secara ekonomis usahatani tidak mengalami keuntungan atau kerugian

$\mathrm{R} / \mathrm{C}<1$ : Secara ekonomis usahatani mengalami kerugian

Perhitungan biaya produksi yang dikeluarkan oleh petani dihitung sesuai petunjuk Hadisapoetro, (1973). 
3. Hasil dan Pembahasan

\subsection{Gambaran Usahatani Kangkung Darat}

Lahan yang digunakan untuk berusahatani kangkung darat merupakan lahan milik sendiri. Luas lahan berkisar antara 3-18 are, untuk lebih jelasnya dapat dilihat pada Tabel 1 .

Tabel 1. Luas Kepemilikan Lahan Petani Kangkung Darat

\begin{tabular}{cccc}
\hline No & Luas Lahan (are) & Jumlah & Persentase (\%) \\
\hline 1 & $3-6$ & 12 & 30 \\
2 & $7-10$ & 11 & 27,5 \\
3 & $11-14$ & 2 & 5 \\
4 & $15-18$ & 15 & 37,5 \\
\hline Jumlah & & 40 & 100 \\
\hline
\end{tabular}

Petani yang berusahatani kangkung darat di desa Takin kebanyakan memiliki luas lahan $15-18$ are $(37,5 \%)$. Hal ini berarti bahwa petani responden tergolong dalam petani kecil yang memiliki luas lahan yang sempit dengan status kepemilikan lahan yaitu lahan milik sendiri. Status kepemilikan lahan yaitu milik sendiri tersebut maka petani lebih bebas dalam melaksanakan usahatani kangkung darat karena lahan telah tersedia.

Tenaga kerja di lokasi penelitian berasal dari tenaga kerja dalam keluarga yang merupakan sumbangan dalam keluarga pada produksi secara keseluruhan. Hal ini tidak dinilai dengan uang (upah tenaga kerja) tetapi hanya menghitung konsumsi. Tahap-tahap budidaya tanaman kangkung darat antara lain persiapan lahan, pemupukan dasar, penanaman, penyiraman, panen dan pasca panen.

a. Persiapan Lahan (Pengolahan Lahan)

Persiapan lahan dilakukan dengan cara tanah dibersihkan dari gulma yang tumbuh di sekitar lahan menggunakan parang, pacul dan linggis. Tanah dibajak menggunakan pacul dan linggis sedalam $20-30 \mathrm{~cm}$ sehingga gembur, setelah itu dibuat bedengan dengan lebar $2 \mathrm{~m}$ dan panjang $10 \mathrm{~m}$ sehingga satu are menghasilkan 5 bedeng dan bedeng tersebut diratakan. Persiapan lahan di lokasi penelitian dilakukan selama $\pm 2-4$ hari tergantung tenaga kerja yang tersedia luas lahan.

\section{b. Pemberian Pupuk Dasar}

Sebelum melakukan penanaman bedengan tersebut diberi pupuk dasar, pupuk dasar yang digunakan di lokasi penelitian adalah pupuk kandang. Pemupukan dilakukan dengan cara pupuk disebarkan pada bedengan lalu dicampur dengan tanah hingga rata. Kegiatan pemupukan di lokasi penelitian rata-rata membutuhkan waktu 1 hari untuk yang lahan sempit dan untuk yang lahannya luas membutuhkan waktu selama 2-3 hari.

\section{c. Penanaman}

Benih yang digunakan untuk penanaman adalah benih yang baik. Benih yang baik adalah benih yang berasal dari tanaman yang sehat, cukup tua, bebas hama dan penyakit serta tidak keriput. Penanaman dilakukan dengan cara pembuatan lubang tanam menggunakan tugal, dan setiap lubang tanam dimasukkan 2-3 biji. Lubang tanam tersebut ditutup kembali menggunakan tanah. Penanaman membutuhkan waktu 2-3 hari untuk yang lahannya luas, dan untuk yang lahan sempit waktu yang digunakan hanya satu hari saja.

\section{d. Pemeliharaan}

Pemeliharaan yang dilakukan pada tanaman kangkung darat di lokasi penelitian adalah penyiraman. Penyiraman dilakukan sehari 2 kali yakni pagi dan sore saat tanaman berumur 1 hari sampai 2 minggu setelah tanam. Saat tanaman berumur 3 minggu setelah tanam, tanaman kangkung disiram 2 hari sekali.

\section{e. Panen dan Pasca Panen}

Kangkung dipanen saat berumur 21-30 hari setelah tanam, atau dengan melihat daun pada kangkung sudah mulai panjang dan batangnya sudah membesar. Panen biasanya dilakukan dengan memotong pada bagian pangkal tanaman kurang lebih $2-3 \mathrm{~cm}$ di atas permukaan tanah menggunakan pisau. Pemanenan di lokasi penelitian dilakukan oleh petani dan ada juga yang dilakukan oleh pedagang karena pedagang langsung mendatangi lahan petani. Pemanenan di lokasi penelitian dilakukan rata-rata 4 hari. Kegiatan pasca panen dilakukan dengan cara, kangkung dibersihkan dari daun yang menguning menggunakan tangan dan batang yang terlalu tua dipotong sebagian menggunakan pisau. Setelah dibersihkan diikat menggunakan tali gewang lalu menyimpan kangkung tersebut pada ember dan karung untuk siap dipasarkan.

\subsection{Analisis Pendapatan Usahatani Kangkung Darat}

a. Penerimaan Usahatani Kangkung Darat

Rata-rata produksi kangkung darat dalam satu kali musim tanam adalah 2.556,25 ikat dengan total produksi 102.250 ikat, dengan harga jual Rp1.000,00 per ikat di tingkat petani maka total penerimaan usahatani kangkung darat di desa Takin dalam satu kali musim tanam sebesar Rp10.2250.000,00 dengan rata-rata penerimaan sebesar Rp2.556.250,00

\section{b. Biaya Produksi Usahatani Kangkung Darat}

Biaya produksi yang dikeluarkan adalah 1) biaya variabel berupa biaya benih, biaya tenaga kerja pengolahan lahan, penanaman, penyiangan, panen dan pasca panen, biaya bensin dan biaya transportasi; dan 2) biaya tetap atau penyusutan alat.

- Biaya Variabel

Rata-rata biaya variabel yang dikeluarkan dalam satu kali proses produksi sebesar Rp300.250,00 dengan total biaya sebesar Rp12.010.000,00. Biaya produksi tersebut terdiri dari beberapa jenis yakni 1) benih kangkung darat dengan total biaya sebesar Rp3.250.000,00 dengan rata-rata biaya sebesar Rp90.625,00; 2) rata-rata biaya konsumsi sebesar Rp43.750,00 dengan total biaya sebesar Rp1.375.000,00; 3) rata-rata biaya bensin sebesar Rp102.750,00 dengan total biaya sebesar Rp4.110.000,00; dan 4) rata-rata biaya transportasi sebesar Rp63.500,00 dengan total biaya sebesar Rp2.540.000,00.

- Biaya Tetap

Biaya tetap dalam penelitian ini meliputi penyusutan alat. Rata-rata biaya penyusutan peralatan yang dikeluarkan petani dalam berusahatani kangkung darat di desa Takin sebesar Rp33.710,40 dari total keseluruhan biaya yang dikeluarkan sebesar Rp1.348.417,00. Biaya tersebut terdiri dari beberapa jenis yakni 1) penyusutan parang dengan total biaya sebesar Rp84.375,00; 2) penyusutan pacul dengan total biaya sebesar Rp137.500,00; 3) penyusutan linggis dengan total biaya sebesar Rp136.875,00;4) penyusutan ember dengan total biaya sebesar Rp674.667,00; 5) penyusutan sekop dengan total biaya Rp147.500,00 dan 6) penyusutan pisau dengan total biaya sebesar Rp165.500,00

\section{c. Pendapatan Usahatani Kangkung Darat}

Pendapatan diperoleh dari selisih penerimaan dengan total biaya yang dikeluarkan. Berdasarkan hasil perhitungan diperoleh total penerimaan sebesar Rp102.250.000,00 dengan rata-rata penerimaan sebesar Rp2.556.250,00 sedangkan total biaya sebesar Rp13.538.416,67 dengan rata-rata biaya sebesar Rp333.960,41. Total pendapatan yang diperoleh petani kangkung darat di desa Takin sebesar Rp88.891.583,33 dengan rata-rata pendapatan sebesar Rp2.222.289,58. Secara jelas dapat dilihat pada Gambar 1. Pendapatan setiap petani ini lebih besar dibandingkan dengan rata-rata pendapatan usahatani kangkung petani di kelurahan Bansone. Menurut Tani'i \& Kune, (2016) rata-rata pendapatan usahatani kangkung di kelurahan Bansone sebesar Rp1.730.694,00.



Gambar 1. Rata-rata Pendapatan Usahatani Kangkung Darat

\subsection{Keuntungan Relatif Usahatani Kangkung Darat}

Dengan total penerimaan sebesar Rp102.250.000,00, total biaya sebesar $\mathrm{Rp} 13.538 .416,67$, rata-rata penerimaan sebesar Rp2.556.250,00, dan rata-rata biaya sebesar Rp333.960,41 maka diperoleh nilai R/C rationya sebesar 7,36. Analisa $\mathrm{R} / \mathrm{C}$ rationya menunjukkan nilai lebih dari 1 oleh karena itu usahatani kangkung darat sangat layak untuk dikembangkan sebab menguntungkan secara ekonomis. Setiap biaya Rp1,00 yang dikeluarkan untuk usahatani kangkung darat akan memperoleh penerimaan sebesar Rp7,36.

\section{Simpulan}

Tahapan usahatani kangkung darat yang dilakukan di desa Takin meliputi persiapan lahan, pemberian pupuk dasar, penanaman, pemeliharaan, panen dan pasca panen. Biaya yang dikeluarkan meliputi biaya tetap dan biaya variabel dengan rata-rata biaya sebesar Rp333.960,41 dan total biaya sebesar Rp13.358.416,67. Total penerimaan usahatani kangkung darat dalam satu kali musim tanam sebesar Rp102.250.000,00 sehingga petani memperoleh rata-rata permintaan sebesar Rp2.556.250,00. Total pendapatan kangkung darat sebesar Rp88.891.583,33 dengan rata-rata pendapatan sebesar Rp2.222.289,58. Ratarata nilai $\mathrm{R} / \mathrm{C}$ Ratio adalah 7,36 sehingga kegiatan usahatani kangkung darat yang dilakukan oleh petani di desa Takin layak untuk dikembangkan karena menguntungkan secara ekonomis.

\section{Pustaka}

Ating, S. \& Sambas, A.M. 2006. Aplikasi Statistika Dalam Penelitian. Bandung: Penerbit Pustaka Setia.

BPS Kab. TTU 2017. Kabupaten Timor Tengah Utara dalam Angka 2017. Kefamenanu: Badan Pusat Statistik Kabupaten TTU.

Hadisapoetro, S. 1973. Pembangunan Pertanian. Yogyakarta: Departemen Ekonomi Pertanian Fakultas Pertanian, Universitas Gadjah Mada. 
Haki, M.G. \& Taena, W. 2017. Analisis Pendapatan Usahatani Cabe Rawit Merah di Desa Tapenpah Kecamatan Insana Kabupaten Timor Tengah Utara. AGRIMOR, 2(04): 57-58

Haryanto, E. 2007. Sawi \& Selada. Revisi ed. Seri Agribisnis. Jakarta: Penebar Swadaya.

Nubatonis, A. 2016. Analisis Pendapatan Usahatani Sawi di Desa Humusu Oekolo Kecamatan Insana Utara Kabupaten Timor Tengah Utara. AGRIMOR, 1(01): 1-2.

Opat, E. \& Hutapea, A.N. 2017. Analisis Pendapatan Usahatani Sawi Manis di Kelurahan Oelami, Kecamatan Bikomi Selatan, Kabupaten Timor Tengah Utara. AGRIMOR, 2(03): 33-35.

Pay, Y.A. \& Nubatonis, A. 2017. Analisis Pemasaran Buncis di Desa Oerinbesi Kecamatan Biboki Tanpah Kabupaten Timor Tengah Utara. AGRIMOR, 2(04): 52-54.

Pitojo, S. 2005. Benih Kacang Tanah. Seri Penangkaran. Yogyakarta: Kanisius. Rahman, M.M. \& Parkpain, P. 2004. Distribution of arsenic in kangkong (Ipomoea reptans). Science Asia, 30: 255-259.

Rukmana, R. 1994. Kangkung. Seri Budi Daya. Yogyakarta: Kanisius.

Soekartawi 1993. Agribisnis: Teori dan Aplikasinya. Jakarta: Raja Grafindo Persada.

Soekartawi 1995. Analisis Usaha Tani. Jakarta: Universitas Indonesia Press.

Sugiyono, 2006. Metode Penelitian Kuantitatif, Kualitatif dan $R \&$ D. Bandung: Alfabeta.

Suratiyah, K. 2006. Ilmu Usahatani. Revisi ed. Jakarta: Penebar Swadaya.

Taena, W. 2009. Kajian Pengembangan Ekonomi Wilayah Perbatasan Kabupaten Timor Tengah Utara dengan District Enclave Oekusi. [Tesis] Institut Pertanian Bogor.

Tani'i, O. \& Kune, S.J. 2016. Analisis Pendapatan Usahatani Sayur Kangkung di Kelurahan Bansone, Kecamatan Kota Kefamenanu, Kabupaten Timor Tengah Utara. AGRIMOR, 1(04): 72-74. 